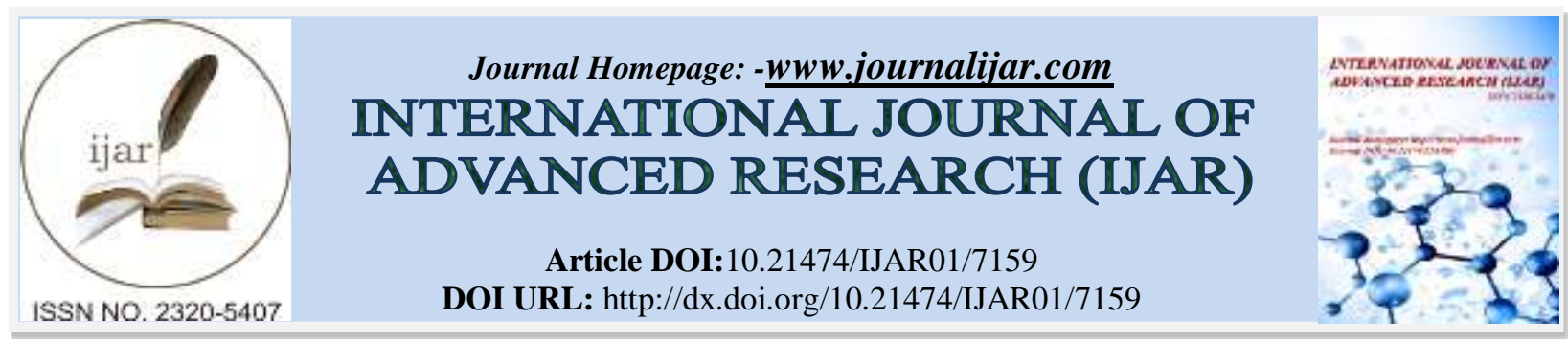

RESEARCH ARTICLE

\title{
SELF EFFICACY AND ACADEMIC ACHIEVEMENT OF HIGH SHOOL STUDENTS FROM MARGINALISED SOCIETY.
}

Dr. M. Kanmani.

\section{Manuscript Info}

(..........................

Manuscript History

Received: 21 March 2018

Final Accepted: 23 April 2018

Published: May 2018

\section{Abstract}

Knowledge has been extolled as super god, as the supreme power. The study aims to find the relationship between self-efficacy and academic achievement of high school students from marginalised society. Survey method was adopted for the study, five hundred samples were randomly selected for the study. The findings of the study revealed that there is no significant correlation between self-efficacy and academic achievement of high school students from marginalised society.

Copy Right, IJAR, 2018,. All rights reserved.

\section{Introduction:-}

Knowledge provides power. The famous Greek Philosopher Aristotle said, "Educated men are as much superior to the uneducated as the living are to the dead". Therefore, the knowledge has been extolled as super god, as the supreme power. Further it has been said, "Education is such a wealth which can neither be stolen by the thieves nor snatched away by the king or government nor can be shared by the brothers and nor burdensome to the individual. The more it is spent, the more it increases. The wealth of knowledge is the supreme wealth of all. Education is enlightenment. Nothing is as enlightening and lustrous as wisdom. Nothing is so purifying on earth as knowledge. The knowledge is like the elixir. Without education man can attain nothing and he cannot be a man.

\section{Review Of Related Literature:-}

Kimberley Hill et.al (2013) investigated the relationship between internalized stigma, negative symptoms and social functioning in schizophrenia: The mediating role of Self-efficacy". The study revealed that self-efficacy was strongly related to negative symptoms and moderately associated with social functioning. Michelle L. Peters(2013) examined the relationships among classroom climate, self-efficacy, and achievement in undergraduate mathematics: a multi-level analysis. The results of the multi-level analysis indicated: (a) students having higher mathematics self-efficacy also had higher mathematics achievement, (b) teacher-centered classroom climates had greater mathematics self-efficacy levels, (c) classroom climate was not a significant predictor of mathematics achievement, (c) classroom climate did not moderate the relationship between mathematics self-efficacy and achievement, and (d) although boys reported higher mathematics self-efficacy than girls, gender differences were not found to exist in regard to mathematics achievement. Yazachew Alemu Tenaw(2013) conducted a study on relationship between self-efficacy, academic achievement and gender in analytical chemistry at Debre Markos College of Teacher Education. The results of the study indicated that students' level of self-efficacy is medium (50.08), and there is statistically significant difference in achievement between gender, and also a significant relationship exists between self-efficacy and achievement. 


\section{Need And Significance Of The Study:-}

Students are the future pillars of the society their achievements are very important. The students perceived selfefficacy. They hoped for expected and actually achieved. Self-efficacy tends to improve when students learn to persists through difficulties and overcome failures and their social behaviors. Hence self-efficacy plays a vital role in every aspect of lie, because it helps the students to reach their goals, regulate their studies and improve their selfesteem. A person with a high level of self-efficacy aces the best representation to do a task, handle on obstacle or a challenging situation.

Basically marginalized students come from the low level of livelihood and they need to develop their standard of life. To lead a well-structured life one must have high confidence which will make them to set themselves with challenging goals and maintain commitment. They can recover quickly after the failures. Lack in the sense of self efficacy affects the self-esteem of the individual. The students should set both long-term and short-term goals. The self-efficacy of marginalized students help to improve the skills like leadership, communication and competitive etc. Hence, the investigator has decided to find is there any relationship between self -efficacy and academic achievement of marginalized high school students.

\section{Objectives Of The Study:-}

1. To find out the level of self-efficacy and academic achievement of high school students from marginalised society.

2. To find out whether there is any significant relationships between self-efficacy and academic achievement of high school students from marginalised society.

3. To find out whether there is any significance difference in self-efficacy of high school students from marginalised society with respect to religion, gender, nature of school, medium of instruction and locality of school

\section{Method Used:-}

Survey method was used for collecting the data.

\section{Samples Selected:-}

Five hundred high school students from marginalised society were randomly selected for the study.

\section{Research Instruments Used For The Study:-}

A scale on self-efficacy was constructed by Dr.M.Kanmani. Content validity was found for the research instrument. The co-efficient of reliability was found using test-retest method and it was found to be 0.67 . Hence the research instrument is found to be highly reliable.

\section{Analysis And Interpretation Of Data:-}

H1: There is no significant correlation between self-efficacy and Academic Achievement of high school students from marginalised society.

Table -1:-Correlation between self-efficacy and Academic Achievement of high school Students marginalised society

\begin{tabular}{|l|l|l|l|l|l|l|l|l|}
\hline $\begin{array}{l}\text { Relationship } \\
\text { between }\end{array}$ & $\sum \mathbf{x}$ & $\sum \mathbf{y}$ & $\sum \mathbf{x 2}$ & $\sum \mathbf{y 2}$ & $\sum \mathbf{x y}$ & $\begin{array}{l}\text { Calculated } \\
\text { value 'r' }\end{array}$ & $\begin{array}{l}\text { Table } \\
\text { value 'r' }\end{array}$ & Remarks \\
\hline $\begin{array}{l}\text { self-efficacy \& } \\
\text { Academic } \\
\text { Achievement }\end{array}$ & 11592 & 10395 & 953248 & 761471 & 805192 & 0.038 & 0.159 & NS \\
\hline
\end{tabular}

NS- Not significant

It is inferred from the above table that the calculated ' $r$ ' value 0.038 is less than the table value of ' $r$ ' $(0.159)$ at 0.05 level of significance. Hence the null hypothesis is accepted. Therefore there is no significant correlation between self-efficacy and academic achievement of students from marginalised society.

H2: There is no significant difference in Self-Efficacy among Hindu, Christian and Muslim high School students from marginalised society. 
TABLE-2

\begin{tabular}{|l|l|l|l|l|l|c|}
\hline $\begin{array}{c}\text { Source of } \\
\text { Variation }\end{array}$ & $\begin{array}{c}\text { Sum of } \\
\text { Variation }\end{array}$ & $\begin{array}{c}\text { Degrees of } \\
\text { freedom }\end{array}$ & $\begin{array}{c}\text { Variance } \\
\text { Estimate }\end{array}$ & $\begin{array}{c}\text { Calculated } \\
\text { Value 'F' }\end{array}$ & $\begin{array}{c}\text { Table Value of } \\
\text { 'F' }\end{array}$ & Remarks \\
\hline Between & 7456.19 & 2 & 3728.09 & & & \\
\hline Within & 49962.07 & 147 & 339.888 & 30.90 & 3.06 & S \\
\hline Total & 57418.25 & 149 & 10.97 & & & \\
\hline
\end{tabular}

s - significant

It is inferred from the above table that the calculated ' $\mathbf{F}$ ' value 30.90 is greater than the table value of (3.06) for $\mathbf{d f}$ $(2,147)$ at 0.05 level of significance. Hence the null hypothesis is rejected. Therefore there is significant difference among the mean score of self-efficacy among Hindu, Christian and Muslim of high School students from marginalised society.

H3:There is no significant difference in Self-Efficacy among boys, girl and Co-education of high School students from marginalised society.

Table-3

\begin{tabular}{|l|l|l|l|l|l|l|}
\hline $\begin{array}{l}\text { Source of } \\
\text { Variation }\end{array}$ & $\begin{array}{l}\text { Sum of } \\
\text { Variation }\end{array}$ & $\begin{array}{l}\text { Degrees of } \\
\text { freedom }\end{array}$ & $\begin{array}{l}\text { Variance } \\
\text { Estimate }\end{array}$ & $\begin{array}{l}\text { Calculated } \\
\text { Value 'F' }\end{array}$ & $\begin{array}{l}\text { Table Value } \\
\text { of 'F }\end{array}$ & $\begin{array}{l}\text { Remarks at 5\% } \\
\text { level }\end{array}$ \\
\hline Between & 4360.63 & 2.00 & 2180.31 & & & \\
\hline Within & 53057.63 & 147.00 & 360.94 & 11.57 & 3.06 & S \\
\hline Total & 57418.25 & 149.00 & 6.04 & & & \\
\hline
\end{tabular}

$\mathrm{s}$ - significant

It is inferred from the above table that the calculated ' $\mathbf{F}$ ' value 11.57 is greater than the table value of (3.06) for $\mathbf{d f}$ $(2,147)$ at 0.05 level of significance. Hence the null hypothesis is rejected. Therefore there is significant difference among the mean score of self-efficacy among boys, girl and Co-education of high School students from marginalised society..

H4: There is no significant difference in Self-Efficacy among Government, Government Aided, Private of high School students from marginalised society.

TABLE-4

\begin{tabular}{|l|l|l|l|l|l|l|}
$\begin{array}{l}\text { Source of } \\
\text { Variation }\end{array}$ & $\begin{array}{l}\text { Sum of } \\
\text { Variation }\end{array}$ & $\begin{array}{l}\text { Degrees of } \\
\text { freedom }\end{array}$ & $\begin{array}{l}\text { Variance } \\
\text { Estimate }\end{array}$ & $\begin{array}{l}\text { Calculated } \\
\text { Value 'F' }\end{array}$ & $\begin{array}{l}\text { Table Value of } \\
\text { 'F' }\end{array}$ & $\begin{array}{l}\text { Remarks at } \\
\mathbf{5 \%} \text { level }\end{array}$ \\
\hline Between & 5979.63 & 2.00 & 2989.31 & & & \\
\hline Within & 51438.63 & 147.00 & 349.94 & 17.17 & 3.06 & S \\
\hline Total & 57418.25 & 149.00 & 8.54 & & & \\
\hline
\end{tabular}

s- Significant

It is inferred from the above table that the calculated ' $F$ ' value 17.17is greater than the table value of (3.06) for $\mathbf{d f}$ $(2,147)$ at 0.05 level of significance. Hence the null hypothesis is rejected. Therefore there is significant difference among the mean score of self-efficacy among Government, Government Aided, Private of high School students from marginalised society.

H5: There is no significant difference in Academic Achievement among Hindu, Christian and Muslim high School students from marginalised society.

Table-5:- Difference in Academic Achievement among Hindu, Christian and Muslim of high School students from marginalised society

\begin{tabular}{|c|c|c|c|c|c|c|}
\hline $\begin{array}{l}\text { Source of } \\
\text { Variation }\end{array}$ & $\begin{array}{l}\text { Sum of } \\
\text { Variation }\end{array}$ & $\begin{array}{l}\text { Degrees of } \\
\text { freedom }\end{array}$ & $\begin{array}{l}\text { Variance } \\
\text { Estimate }\end{array}$ & $\begin{array}{l}\text { Calculated } \\
\text { Value 'F' }\end{array}$ & $\begin{array}{l}\text { Table } \quad \text { Value } \\
\text { of 'F' }\end{array}$ & Remarks \\
\hline Between & 485.69 & 2.00 & 242.84 & & & \\
\hline Within & 40611.81 & 147.00 & 276.27 & 61.57 & 3.06 & $S$ \\
\hline Total & 41097.50 & 149 & 0.88 & & & \\
\hline
\end{tabular}

s - Significant 
It is inferred from the above table that the calculated ' $\mathbf{F}$ ' value 61.57 is greater than the table value of (3.06) for $\mathbf{d f}$ $(2,147)$ at 0.05 level of significance. Hence the null hypothesis is rejected. Therefore there is significant difference among the mean score of the Academic Achievement among Hindu, Christian and Muslim of high School students from marginalised society.

H6: There is no significant difference in Academic Achievement among Government, Government Aided, Private high School students from marginalised society.

Table-6:-Difference in Academic Achievement among Government, Government Aided, Private of high School students from marginalised society.

\begin{tabular}{|l|l|l|l|l|l|l|}
\hline $\begin{array}{l}\text { Source of } \\
\text { Variation }\end{array}$ & $\begin{array}{l}\text { Sum of } \\
\text { Variation }\end{array}$ & $\begin{array}{l}\text { Degrees of } \\
\text { freedom }\end{array}$ & $\begin{array}{l}\text { Variance } \\
\text { Estimate }\end{array}$ & $\begin{array}{l}\text { Calculated } \\
\text { Value 'F' }\end{array}$ & $\begin{array}{l}\text { Table } \\
\text { of 'F' }\end{array}$ & Value \\
\hline Between & 226.00 & 2.00 & 113.00 & & & Remarks \\
\hline Within & 40871.50 & 147.00 & 278.04 & 64.75 & 3.06 & S \\
\hline Total & 41097.50 & 149 & 0.41 & & \\
\hline
\end{tabular}

s- Significant

It is inferred from the above table that the calculated ' $\mathbf{F}$ ' value 64.75 is greater than the table value of (3.06) for $\mathbf{d f}$ $(2,147)$ at 0.05 level of significance. Hence the null hypothesis is rejected. Therefore there is significant difference among the mean score of the Academic Achievement among Government, Government Aided, Private of high School students from marginalised society.

H7:There is no significant difference in Academic Achievement between Male and Female of high School students from marginalised society.

Table-7:-Difference in Academic Achievement between Male and Female high School students from marginalised society.

\begin{tabular}{|l|l|l|l|l|l|l|c|}
\hline Gender & N & Mean & S.D & $\begin{array}{l}\text { Calculated } \\
\text { Value 't' }\end{array}$ & df & $\begin{array}{l}\text { Table value of } \\
\text { 't' }\end{array}$ & $\begin{array}{l}\text { Remarks } \\
\mathbf{5 \%} \text { level }\end{array}$ \\
\hline Male & 68.71 & 64.71 & 15.55 & 3.22 & 148 & 1.98 & S \\
\hline Female & 82.00 & 73.11 & 16.39 & & & & \\
\hline
\end{tabular}

$\mathrm{S}-$ significant

It is inferred from the above table that the calculated ' $t$ ' value 3.22 is greater than the table value of (1.98) for df at 0.05 level of significance. Hence the null hypothesis is rejected. Therefore there is significant difference between Male and Female high School students from marginalised society.

H8: There is no significant difference in Academic Achievement between Tamil and English Medium of high School students from marginalised society.

Table-8:-Difference in Academic Achievement between Tamil and English Medium of high School students from marginalised society.

\begin{tabular}{|l|l|l|l|l|l|l|c|}
\hline Gender & $\mathbf{N}$ & Mean & S.D & $\begin{array}{l}\text { Calculated } \\
\text { Value 't' }\end{array}$ & df & $\begin{array}{l}\text { Table value of } \\
\text { 't' }\end{array}$ & $\begin{array}{l}\text { Remarks at 5\% } \\
\text { level }\end{array}$ \\
\hline Tamil & 138 & 68.33 & 16.12 & 2.35 & 148 & 1.98 & S \\
\hline English & 12.00 & 80.50 & 17.31 & & & & \\
\hline
\end{tabular}

s-significant

It is inferred from the above table that the calculated' $t$ ' value 2.35 is greater than the table value of (1.98) for df at 0.05 level of significance. Hence the null hypothesis is rejected.Therefore there is significant difference between Tamil and English Medium of high School students from marginalised society.

H9: There is no significant difference in Academic Achievement between Urban and Rural area of high School students from marginalised society. 
Table-9:-Difference in Academic Achievement between Urban and Rural area of high School students from marginalised society.

\begin{tabular}{|l|l|l|l|c|l|l|l|}
\hline Gender & $\mathbf{N}$ & Mean & $\mathbf{S . D}$ & $\begin{array}{l}\text { Calculated } \\
\text { Value 't' }\end{array}$ & $\mathbf{d f}$ & $\begin{array}{l}\text { Table value of } \\
\text { 't' }\end{array}$ & $\begin{array}{l}\text { Remarks at 5\% } \\
\text { level }\end{array}$ \\
\hline Urban & 85 & 72.73 & 16.57 & 3.02 & 148 & 1.98 & $\mathrm{~S}$ \\
\hline Rural & 65 & 64.82 & 15.42 & & & & \\
\hline
\end{tabular}

s - Significant

It is inferred from the above table that the calculated ' $t$ ' value 3.02 is greater than the table value of (1.98) for df 148 at 0.05 level of significance. Hence the null hypothesis is rejected. Therefore there is significant difference between Urban and Ruralof high School students from marginalised society.

\section{Findings Of The Study:-}

1. Self-efficacy and Academic Achievement of high school students from marginalised society did not correlate significantly.

2. There is significant difference in self- efficacy among Hindu, Christian and Muslim high school students from marginalised society.

3. There is significant difference in self-efficacy among Boys, Girls and Co-education high school students from marginalised society.

4. There is significant difference in self-efficacy among Government, Government Aided and Private high school students from marginalised society.

5. There is significant difference in academic achievement among Hindu, Christian and Muslim high school students from marginalised society.

6. There is significant difference in academic achievement among Government, Government Aided and Private high school student from marginalised society.

7. There is significant difference in academic achievement between male and female high school students from marginalised society.

8. There is significant difference in academic achievement between Tamil and English Medium high school students from marginalised society.

9. There is significant difference in academic achievement between urban and rural area high school students from marginalised society.

\section{Conclusion:-}

The purpose of the present investigation was to study the level of Self-Efficacy and academic achievements among school students belonging to MARGINALISED. This indicated significant relationship among variables. The study may be found to useful in the field of education. The findings of this study may serve as database for the future research. Therefore this study suits to the above mentioned to implement the findings, recommendations and suggestions in the high school education level. 


\section{Bibliography:-}

1. Bhagirthi Sahu (2002), The New Educational Philosophy $1^{\text {st }}$ education page (52) Darya Ganj, New Delhi110002.

2. David G. Myers (2007). Social Psychology 8 th education page (57) Tata McGraw Publishing Company Limited, New Delhi 110008.

3. Duane P.Schultz (2002), Psychology and Work Today Eight Edition page: (166-167) Published by Dorling Kindersley (India)South Asia.

4. John W.Santrock (2005), Psychology: Essentials $2^{\text {nd }}$ education page (364-485) TataMcGraw-Hill Publishing Company limited, New Delhi.

5. Mahendra Kumara Seth (2006) MARGINALISED Student Access to Education Challenges and Opportunities page (5-7) Abhijeet Publications Delhi.

6. Robert S. Feldman (2002), Understanding Psychology Sixth Education page (424) Publishing Tata McGrawHill Publishing Company Limited, New Delhi.

7. DISSERTATION ABSTRACTS INTERNATIONAL

8. Kimberley Hill, Mike Startup (2013), "The relationship between internalized stigma, negative symptoms and social functioning in schizophrenia: The mediating role of self-efficacy". Vol.206.No.2-3.p.151-157.

9. Michhelle L.Peters (2013), "Examining the relationship among classroom climate self-efficacy and achievement in undergraduate mathematics multi-level analysis" Vol.11.N.2.p.459-480.

10. Yazachew Alemu Tenaw (2013). "Relationship between self-efficacy, academic achievement and gender in analytical chemistry at debre markos college of teacher education" Vol.3.No.1.P.2227.5835. 